\title{
Vertical transmission and successive location of symbiotic bacteria during embryo development and larva formation in Corticium candelabrum (Porifera: Demospongiae)
}

\author{
Sònia de Caralt**, María J. Uriz ${ }^{\dagger}$ and René H. Wijfels* \\ *Food and Bioprocess Engineering Group, Wageningen University, PO Box 8129, 6700 EV Wageningen, The Netherlands. \\ ${ }^{\dagger}$ Centre d’Estudis Avançats de Blanes (CEAB), CSIC, Accés a la Gala Sant Francesc, 14, 17300 Blanes, Girona, Spain. \\ "Corresponding author, e-mail: sonia@ceab.csic.es
}

\begin{abstract}
This study reports on the transfer of heterotrophic bacteria from parental tissue to oocytes in the Mediterranean bacteriosponge Corticium candelabrum (Homosclerophorida) and the description of the successive locations of the microsymbionts during embryo development through transmission and scanning electron microscopy. Eight different types of symbiotic bacteria are described morphologically. These eight bacteria morphotypes are found in both adult individuals and larvae. Symbiotic bacteria are transferred to oocytes, but not to spermatocytes. Bacteria are first located at the oocyte periphery below a thick collagen layer and then they migrate to the oocyte cytoplasm, forming spherical clusters. After cleavage, the bacteria can be found in the free space between blastomeres but mainly accumulate at the embryo periphery below the follicular cells that surround the embryo. Once the blastocoel is formed, the symbiotic bacteria move to this central cavity where they actively divide by bipartition, increasing their number considerably. Many examples of phagocytosed bacteria in the proximal zone of the larval cells are observed at this stage. Consequently, bacteria may represent a complementary source of energy for free larvae and settlers before they are able to capture food from the surrounding water.
\end{abstract}

\section{INTRODUCTION}

Microbial symbionts are plentiful in many sponge species (e.g. Vacelet, 1975) in such a way that it has been speculated that remineralization of the organic matter in the water column would be the main sponges' role in benthic ecosystems, thanks to their symbiotic populations (Jiménez \& Ribes, 2007). Sponge microsymbionts belong to different taxonomical entities: zooxanthellae (e.g. Rosell \& Uriz, 1992), cyanobacteria (e.g. Turon et al., 2000), and heterotrophic bacteria (e.g. Vacelet, 1975; de Caralt et al., 2003), and can represent a significant part of the sponge volume (e.g. up to 30-50\%, Vacelet, 1975). Yeasts (e.g. Maldonado et al., 2005), and viruses (e.g. Lohr et al., 2005) have also been reported to live within sponges but whether these micro-organisms are parasites or symbionts has not been elucidated yet.

Due to their abundance, microsymbionts are assumed to be important for the biology and ecology of the sponge, although their functions are unknown in most cases. It has been reported that photosynthetic microsymbionts have a role in sponge nutrition (e.g. Sarà, 1971; Wilkinson \& Vacelet, 1979; Rosell \& Uriz, 1992). Wilkinson \& Vacelet, (1979) showed that cyanobacteria transfer nutrients such as glycogen to the host sponges. Moreover, Rosell \& Uriz (1992) recorded significantly higher growth rates in clionid sponges cultured under a light regime than in those maintained in the dark, and attributed these differences to the zooxanthellae primary production. Sarà (1971) suggested that sponges benefit from these micro-organisms by phagocytosis of excess symbionts. On the other hand, the bacterial symbionts can benefit from the nitrogen-rich medium provided by the host sponge in the form of ammonia (e.g. Jiménez \& Ribes, 2007). Microbial symbionts may also be responsible for the production of bioactive compounds (e.g. Piel, 2006).

Microbial symbionts also occur in sponge larvae. Sponge larvae have been reported to harbour bacteria and zooxanthellae (e.g. Mariani et al., 2001). Thus, as in adults, symbiotic micro-organisms might represent a non-negligible source of food for larvae, complementary to (or involved in) the reported incorporation of dissolved organic molecules (Jaeckle, 1995).

One remarkable case is that of Crambe crambe (Schmidt, 1862), in which symbiotic bacteria are reported to be present in the larva but not in the adults (Uriz et al., 2001). Adults of $C$. crambe contain spherulous cells with antibacterial properties, which may prevent the presence of symbiotic bacteria. In contrast, spherulous cells are absent in the larvae and, consequently, larvae can harbour bacteria. As a result, C. crambe larvae may benefit from their symbionts during their pre-feeding stage (Uriz et al., 2001).

Sponge microsymbionts can be intra- and extracellular. Zooxanthellae are found inside the archaeocytes (Mariani et al., 2001), and specialized cells called bacteriocytes harbour heterotrophic bacteria. Moreover, cyanobacteria and 
heterotrophic bacteria can coexist in the same species, spread through the sponge mesohyl (e.g. Usher et al., 2004).

The larvae of bacteriosponges also contain abundant bacteria (e.g. Ereskovsky \& Tokina, 2004), which can be acquired by two different ways: vertical transmission from adults and de novo acquisition from the environment. No evidence of de novo acquisition has been documented in sponges, although the finding of similar bacteria in taxonomically distant sponges inhabiting the same cave has been interpreted as indirect proof of de novo acquisition (Muricy et al., 1999; Enticknap et al., 2006). Moreover, a recent study presents some evidence of similar microbial types in different sponges, which pose the question about the mechanism of their acquisition. In contrast, several instances of vertical transmission have been reported in recent years (e.g. Usher et al., 2005).

Homosclerophorids are a particularly suitable sponge group for studying bacterial transmission because some genera of this group examined so far, are bacteriarich (Corticium and Plakina, e.g. Ereskovsky \& BouryEsnault, 2002). Moreover, larvae of various genera of homosclerophorids (e.g. Plakina, Pseudocorticium and Corticium) have been reported to contain symbiotic bacteria identical to those present in the parent sponge (Boury-Esnault et al., 2003), but transfer of bacteria from parents to larvae has only been documented in Oscarella spp. (Ereskovsky \& Boury-Esnault, 2002). The present study reports on the transfer of heterotrophic bacteria from parental tissue to oocytes in the bacteriosponge Corticium candelabrum Schmidt, 1862 (Homosclerophorida), describing the successive locations of bacteria during embryo and larval development. We also describe and compare the several morphotypes of bacteria present in adults and larvae, through electron microscopy.

\section{MATERIALS AND METHODS}

Samples of Corticium candelabrum were collected during the reproductive period (Spring-Summer, 2002) by SCUBA diving in the western Mediterranean (Blanes), at a depth of $7-12 \mathrm{~m}$. Once in the laboratory subsamples of about $3 \mathrm{~mm}^{3}$ in size were fixed for transmission electron microscopy (TEM) and scanning electron microscopy (SEM) observations.

Samples for TEM were fixed in a mixture of $1 \% \mathrm{OsO}_{4}$ and $2 \%$ glutaraldehyde in $0.45 \mathrm{M}$ sodium acetate buffer (pH 6.4) with 10\% sucrose (1/3) (Leys \& Reiswig, 1998), dehydrated in an alcohol series and embedded in Spurr resin. Ultrathin sections were stained with uranyl acetate and lead citrate and then observed under a Hitachi H-600 transmission electron microscope (Microscopy Unit of the Scientific and Technical Services of the University of Barcelona). For SEM observations, samples were fixed with a mixture of $2 \% \mathrm{OsO}_{4}$ and saturated $\mathrm{HgCl}_{2}(6 / 1)$ for $90 \mathrm{~min}$ (Johnston \& Hildemann, 1982), dehydrated in an ethanol series, critical-point dried, mounted and sputter-coated with gold-palladium, and examined through a Hitachi-2300 scanning electron microscope (Institute of Marine Sciences of Barcelona, CSIC).

The proportion of symbiotic bacteria/sponge tissue has been derived from ten TEM pictures taken at random from three samples of adult sponge tissue.
Bacteria morphotypes (from both adults and embryos) were characterized through TEM. The main phenotypic characters considered were size and general shape, the bacteria wall, the presence or absence of periplasm, the number of membranes, the nuclear region, and the cytoplasm density.

\section{RESULTS}

Adults

Symbiotic bacteria represent $\sim 40.74 \pm 6.58 \%$ (mean \pm SE) of the Corticium candelabrum tissue as calculated from the sponge section pictures. The symbiotic bacterial population, which is extracellular, is embedded in collagen (Figure 1). Symbiotic bacteria are isolated from the choanocyte chambers by a thick collagen layer. Eight different phenotypic bacterial types can be recognized in the adult tissue (Figure 2). Bacteria types B, C, D, F, G and H have complex cell walls, typical of gram-negative bacteria.

Type (A). Large (to a maximum of $~ 3.1 \mu \mathrm{m}$ in length, and $\sim 1.2 \mu \mathrm{m}$ in width), cylindrical to ovoid bacteria. The cell is surrounded by two close membranes ( 30-40 nm thick altogether), the inner one (cytoplasm membrane) poorly differentiated from the cell cytoplasm. The cytoplasm is electron-dense, without a distinct nuclear region. This bacteria type is relatively abundant and the largest one recorded in the adult sponge tissue.

Type (B). About $0.7-1.3 \mu \mathrm{m}$ in length and $\sim 0.6-0.8 \mu \mathrm{m}$ in width, bacteria. The cell has a double membrane separated by a relatively wide $(\sim 60 \mathrm{~nm})$, electron-clear, periplasm. The external membrane (cell wall), $\sim 10 \mathrm{~nm}$ in thickness, is dark and well delimited. The cytoplasm is loose at the central zone and denser at the periphery of the cell. The nucleoid (electron-clear zones) is spread across the cytoplasm.

Type (C). Medium-sized ( 1.3-1.5 $\mu \mathrm{m}$ in length and $\sim 0.9$ $\mu \mathrm{m}$ in width), variable in shape (from triangular to circular in transversal sections) bacteria with a very wide (up to $180 \mathrm{~nm}$ ) cover consisting of two layers separated by a well developed, electron-clear periplasm. The internal matrix is granulated, with one highly electron-dense spot (not always visible in the sections). The nuclear region is large and occupies almost the whole cell.

Type (D). Cylindrical, $\sim 1 \mu \mathrm{m}$ in length and $\sim 0.7 \mu \mathrm{m}$ in width, bacteria. Thick cover consisting of a cytoplasmic membrane, a very wide $(\sim 0.2 \mu \mathrm{m})$ medium electron-dense (grey) periplasm, which is wider at the two cell poles, and an electron-dense membrane (cell wall). The cytoplasmic membrane projects several folds towards the periplasm (vesicular aspect). The nuclear region is large, mainly located at the centre of the cell, surrounded by a granular electrondense cytoplasm.

Type (E). Cylindrical, slightly irregular in cross-section $(\sim 1.4-0.7 \mu \mathrm{m}$ in diameters) bacteria with the cytoplasmic membrane and the cell wall intimately in contact (without periplasm). The nucleoid is large and occupies a central position while the cytoplasm is mainly relegated to the periphery with electron-dense granules in close contact with the cytoplasmatic membrane.

Type (F). Cylindrical $(\sim 1.1 \mu \mathrm{m}$ in length and $\sim 0.5 \mu \mathrm{m}$ in width) bacteria with two membranes separated by a poorly developed periplasm $(\sim 20 \mathrm{~nm})$. The cell wall is finely 



Figure 1. (A) TEM picture of symbiotic bacteria in adult tissue of Corticium candelabrum: ch, choanocytes forming a chamber; b, high amounts of bacteria belonging to several morphotypes; (arrowhead) collagen mass in the chamber light. (B) TEM picture of a detail of symbiotic bacteria in adult tissue of $C$. candelabrum: b, extracellular bacteria; co, thick collagen layer surrounding the bacteria; ch, choanocyte separated from the bacteria by the collagen layer.
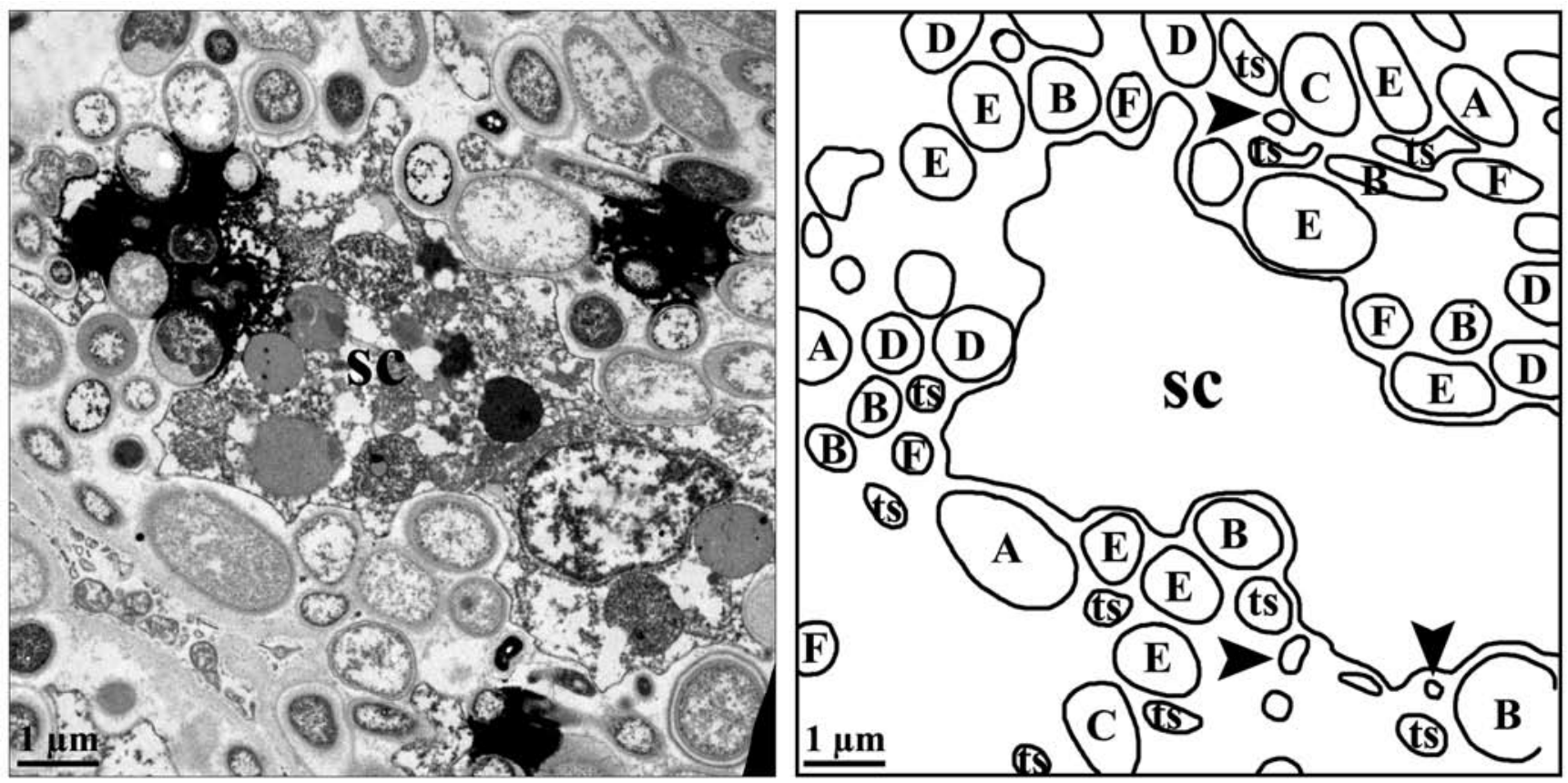

Figure 2. TEM picture showing the eight types of symbiotic bacteria (from $\mathrm{A}$ to $\mathrm{H}$ in the scheme) observed in adult tissue of Corticium candelabrum (see text for description of the characteristic of each type): sc, sponge cell.

undulated. The internal matrix is very dense and granular without a conspicuous nuclear region.

Type (G). Cylindrical $(\sim 1.2 \mu \mathrm{m} \times 0.8 \mu \mathrm{m})$ bacteria with a complex cover consisting of three conspicuous membranes. The two internal ones are close to each other, separated from the most external and darker membrane by an electron-clear, $\sim 70 \mathrm{~nm}$ width, periplasm. The cytoplasm is very dense and uniformly granulated. No nuclear region is visible.
Type $(\mathrm{H})$. Small $(\sim 0.8 \mu \mathrm{m} \times 0.2 \mu \mathrm{m})$, irregularly elongated bacteria, with a uniform, very electron-dense, cytoplasm (completely black in our pictures) and without a conspicuous nuclear region. An electron-clear periplasm separates the 'black' area from the external membrane (cell wall), which is less electron-dense than the cytoplasm.

Taking into consideration the many sections observed, we can state that most of the bacteria types are similarly 

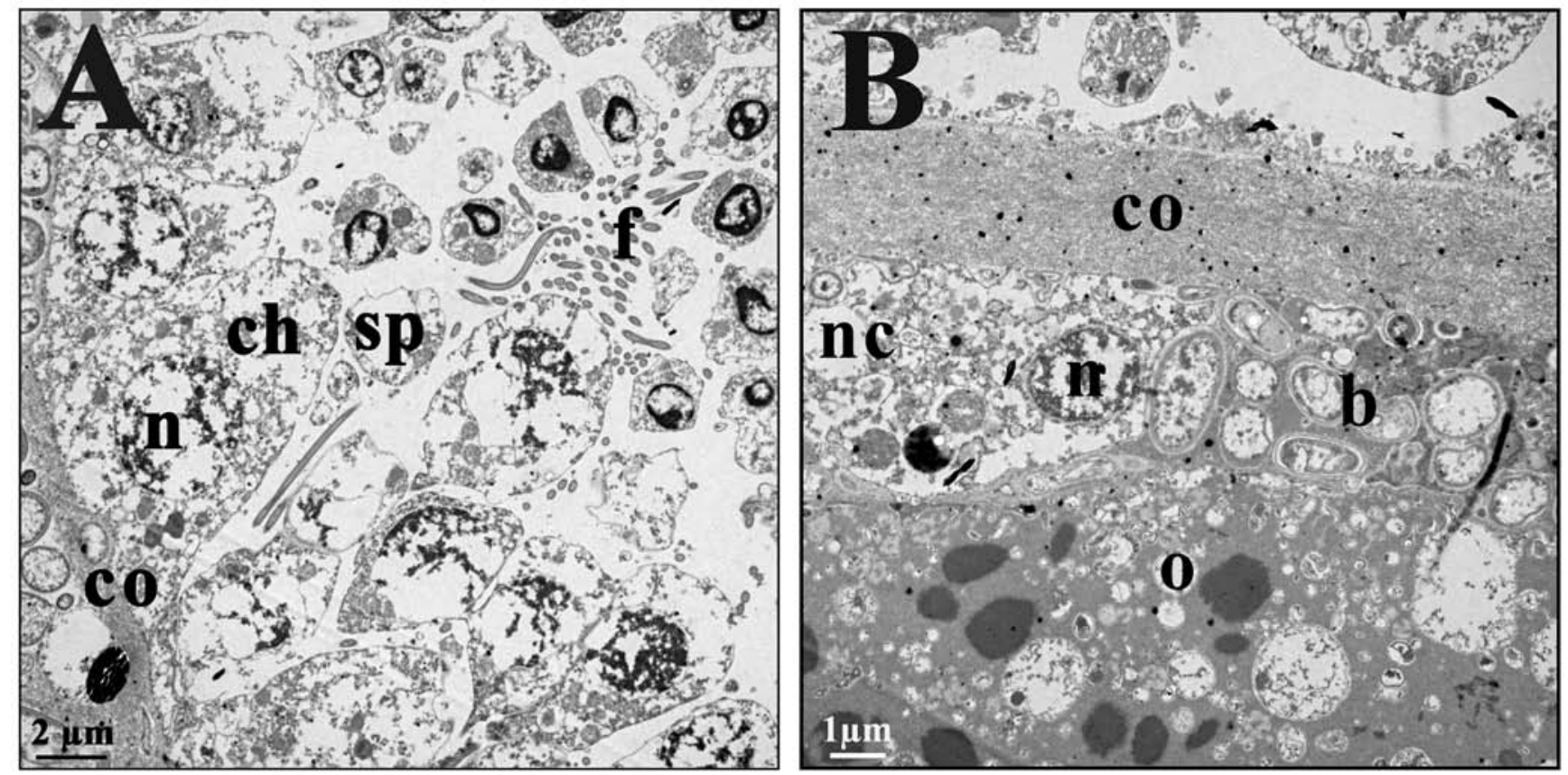

Figure 3. (A) TEM picture of an early stage of spermatogonia of Corticium candelabrum (note the absence of bacteria): ch, choanocyte; $n$, choanocyte nucleus; sp, spermatid; f, flagella; co, collagen layer surrounding the spermatogonia; (B) TEM picture of a later (fertilized?) oocyte of $C$. candelabrum surrounded by bacteria: o, oocyte; nc, nurse cells surrounding the oocyte; n, nucleus of the nurse cells; b, bacteria at the oocyte periphery; co, thick collagen layer surrounding the nurse cells.

frequent in the adult tissue. Only types $\mathrm{A}$ and $\mathrm{H}$ appear to be more abundant (two and three times more frequent than the other types, respectively). No instances of phagocytosis have been shown in the many pictures of adult tissue.

\section{Gametes}

Although C. candelabrum is a hermaphrodite species, symbiotic bacteria are only transferred to oocytes while spermatogonia are bacteria-free.

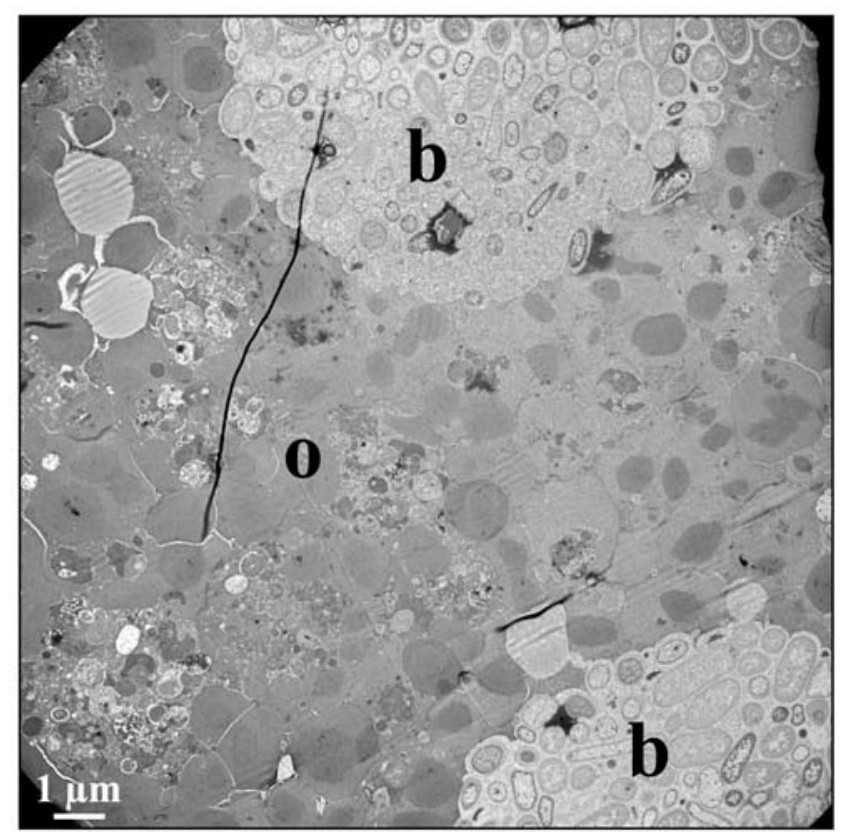

Figure 4. TEM picture of an oocyte of Corticium candelabrum with bacteria concentrated in two spherical clusters: o, oocyte; b, bacteria.
Since spermatocysts originate from choanocyte chambers, the thick collagen layer that surrounds the functional choanocyte chambers is maintained during spermatogonia formation preventing the entrance of symbiotic bacteria (Figure 3A).

In contrast, the oocytes, are in direct contact with the parental mesohyl. Thus, all types of symbiotic bacteria seem to be transferred directly during oocyte growth, together with the nurse cells from the adult. A collagen layer surrounds the oocyte (Figure 3B).

Mature (100-150 $\mu \mathrm{m}$ in diameter) oocytes have symbiotic bacteria inside the cytoplasm. At this stage, in which the oocyte cytoplasm is filled with yolk granules and some lipids, the symbiotic bacteria are concentrated in spherical clusters resulting from bacteria that migrated from the oocyte periphery (Figure 4). Bacterial clusters are in direct contact with the oocyte cytoplasm without any surrounding collagen layer, or membrane. The eight different morphotypes present in the adults are found with a similar relative abundance in the oocyte (Figure 5). The types $\mathrm{A}$ and $\mathrm{H}$, as in adults, are the most abundant bacteria in both the oocyte and embryo. Bacteria clusters in the oocyte increase in size by bacterial bipartition. The similarity between adult and embryo bacteria suggests that all the bacterial types are transmitted directly from parental tissue to oocytes (vertical transmission).

\section{Embryo}

During cleavage, follicular cells and a thin collagen layer surround the embryo. When the blastomeres start to form (initial cleavage phase), the spherical clusters of bacteria disaggregate and most bacteria are pushed to the embryo periphery although some of them can be found in the free space among blastomeres (Figure 6). 

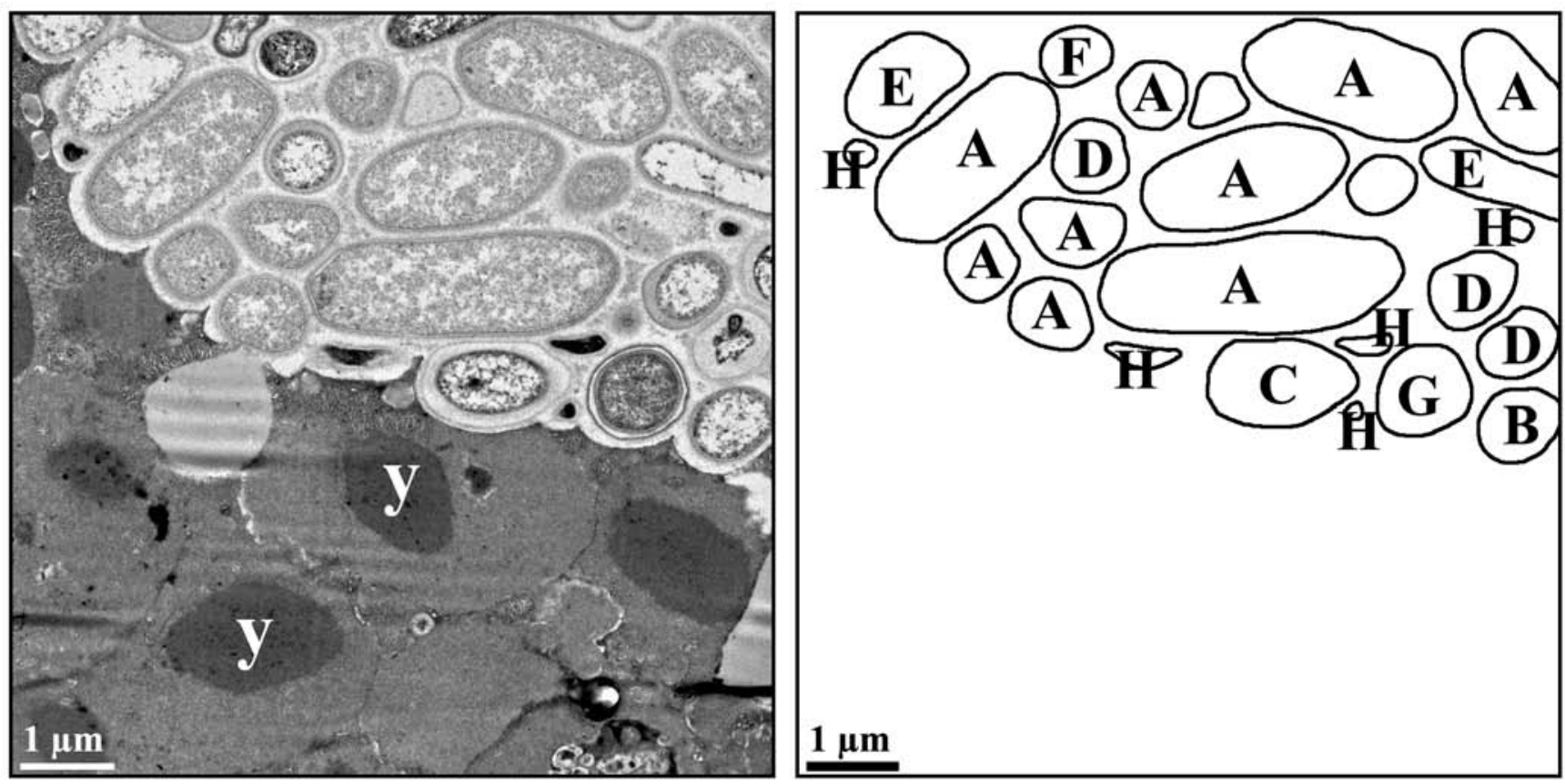

Figure 5. TEM picture of the bacteria types in an oocyte of Corticium candelabrum (see text for description of the characteristic of each type; letters correspond to the same type as in the adult): y, yolk granules of the oocyte.
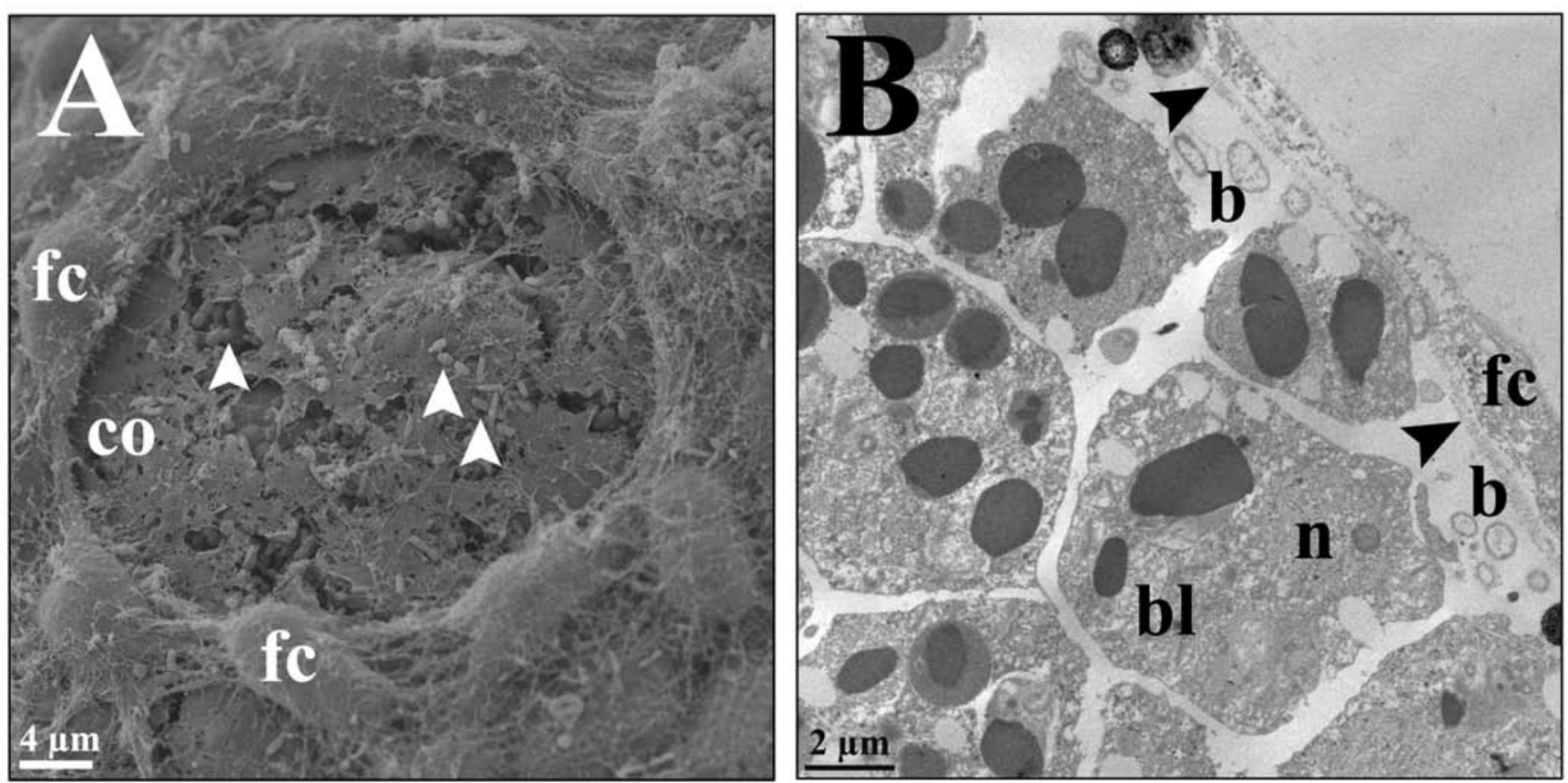

Figure 6. (A) SEM picture of the surface of a Corticium candelabrum embryo covered by the follicular layer. Some follicular cells were removed to show the collagen layer surrounding the embryo: fc, follicular cells; co, collagen layer; (arrowheads) bacteria; (B) TEM picture of an embryo of C. candelabrum: bl, blastomeres; n, nucleus of the blastomeres; b, bacteria at the embryo periphery; co, collagen layer surrounding the embryo; fc, follicular cells.

When the internal cavity (blastocoel) starts to form by multipolar egression (i.e. from the centre of the embryo to the periphery), the symbiotic bacteria migrate from the embryo periphery to this internal cavity, which also contains dispersed collagen fibrils.

\section{Larvae}

Bacteria within the internal cavity of the mature embryo increase in number by bipartition as the larval cavity also increased in size (blastocoel). The bacterial population of the completely formed blastocoel consists of the same morphotypes found in the adults (Figure 7A-C). A discrete collagen layer, considered to correspond to a basement membrane (Boury-Esnault et al., 2003), separates the pseudostratified layer of larval cells from the bacterial population inside the blastocoel (Figure 7D).

Many instances of phagocytosed bacteria are observed at the proximal zone of the larval cells, close to the blastocoel 


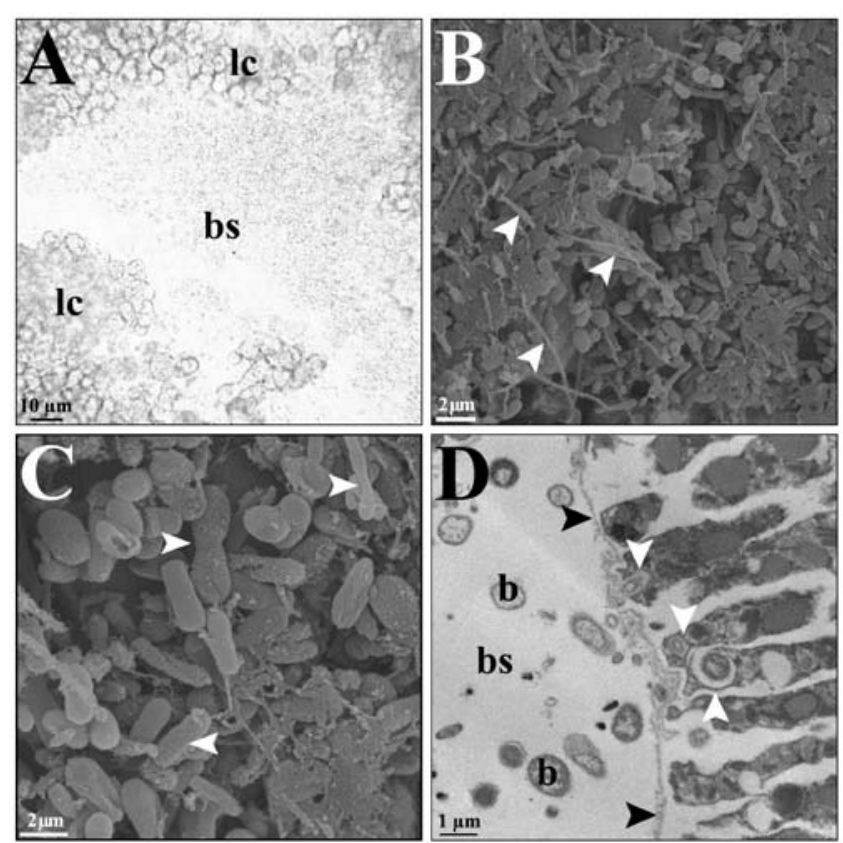

Figure 7. (A) Light microscopy picture of a Corticium candelabrum larva: bs, blastocoel full of bacteria; lc, larval cells; (B) SEM image of a broken larva of C. candelabrum releasing the inner bacteria: (arrowheads) larva cilia; $(\mathrm{C})$ detail of the broken larvae in $(\mathrm{B})$. SEM image of several bacterial morphotypes: (arrowheads) detail of a bacteria bipartition; (D) TEM image of a C. candelabrum larva: bs, completely formed blastocoel; (black arrowheads) collagen layer (i.e. basement membrane) at the base of the pseudostratified larval cells; b, free bacteria in the blastocoel; (white arrowheads) engulfed bacteria in the proximal zone of larval cells.

(Figure 7D). In contrast, the distal zone of the cells is bacteria free. Phagocytosis of bacteria seems to be a particular feature of larval cells since no instances of engulfed bacteria have been found in adult tissues.

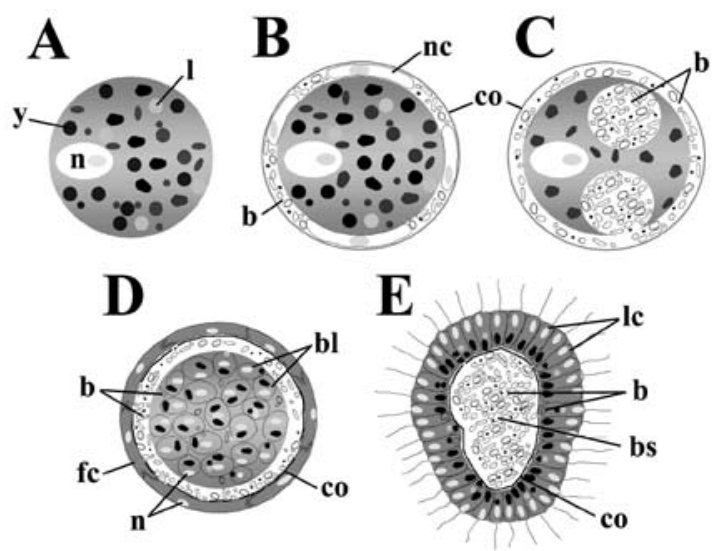

Figure 8. Schematic representation of the successive location of bacteria from oocyte to larva in Corticium candelabrum. (A) Oocyte: n, nucleus; y, yolk granules; l, lipids; (B) fertilized oocyte: nc, nurse cells; b, bacteria; co, collagen layer; $(\mathrm{G})$ oocyte before cleavage with spherical clusters of bacteria: co, collagen layer; b, bacteria; (D) embryo: co, collagen layer; fc, follicular cells; b, bacteria mainly located at the periphery and also in the free space between blastomeres; bl, blastomeres; n, nucleus; (E) completely formed cinctoblastula: lc, larval cells; co, collagen layer/basement membrane; bs, blastocoel; b, bacteria inside the blastocoel and also phagocytosed by larval cells.
The whole process of the vertical transmission of symbiotic bacteria in $C$. candelabrum is schematically illustrated in Figure 8: bacteria are transferred from parental tissue during early stages of oogenesis. The transferred bacteria replicate inside the oocyte, forming bacteria clusters. Embryogenesis involves bacteria proliferation among blastomeres and mainly at the embryo periphery below the collagen layer. Once the blastocoel is formed, bacteria accumulate in this fluid-filled cavity. Thus, the free larvae consist of a layer of ciliated cells surrounding a bacteria-filled blastocoel.

\section{DISCUSSION}

Bacteriosponges are found in most orders of Demospongiae but are particularly abundant among the Dictyoceratida, Chondrosida, Verongida, Astrophorida and in some genera of Homosclerophorida. The way that the bacteria of bacteriosponges are acquired by the progeny is an issue repeatedly dealt with in the literature. Vertical transmission is the most often reported mechanism (e.g. Usher et al., 2005; Enticknap et al., 2006) and favours mutualism to evolve.

In Corticium candelabrum, vertical transmission of microsymbionts occurs before oocyte fertilization and cleavage take place, as has been reported for other homosclerophorids (Ereskovsky \& Boury-Esnault, 2002). With the information at hand, transmission before cleavage seems to be a rule for cinctoblastula producers (Homosclerophorida) and for oviparous sponges (e.g. authors' personal observations). In contrast, bacterial transmission seems to take place during cleavage in most larviparous sponges that produce solid larvae (parenchymella) (e.g. Kaye \& Reiswig, 1991). In oviparous sponges, oocytes surrounded by a pseudo-chorion are released to the environment before cleavage takes place (Mariani et al., 2001) and, thus, only during oocyte formation can microsymbionts be acquired from the sponge parental tissue. Similarly, in C. candelabrum, bacteria are transferred to the oocyte when it is in contact with the parental tissue (i.e. before fertilization), whereas at later stages (fertilized oocyte), a follicular layer (Figure 5) isolates the zygote from the parental tissue.

The cinctoblastula of $C$. candelabrum has the same morphotypes of symbiotic bacteria as the adults, which confirms that all bacterial types are transferred parentally. These observations point to a species-specificity of the symbiotic bacteria of $C$. candelabrum as has been reported for other homosclerophorids (e.g. Muricy et al., 1999; Ereskovsky \& Boury-Esnault, 2002).

This is the first time that phagocytosis of bacteria has been abundantly recorded in larvae of a homosclerophorid. However, it was not observed in adults, probably due to the presence of a dense collagen layer, which isolates bacteria from the sponge tissue (de Caralt et al., 2003). This clear separation between bacteria and sponge cells seems to be a particular feature of $C$. candelabrum (and maybe of Homosclerophorida in general) since it has not been reported for any other bacteriosponge examined to date (e.g. Kaye \& Reiswig, 1991; Ereskovsky \& Tokina, 2004).

A nutritional role has been speculated for bacteria phagocytosis by sponge cells but control of symbionts proliferation (housekeeping) could also be speculated. In $C$. 
candelabrum, only during larval stages are bacteria in contact with sponge cells and then only in these stages bacteria may represent a supplementary source of nutrients as the most likely function. This extra food may contribute to enlarging the competence period of free larvae, and to increase the success of settlers before their feeding system (aquiferous system) is developed and the filtering activity provides the sponge with external food. On the other hand, although phagocytosis of bacteria has not been previously reported in larvae of homosclerophorids, it has been repeatedly documented in parenchymellae of Dictyoceratida (e.g. Ereskovsky \& Tokina, 2004) and thus it seems to represent a non-negligible source of nutrients for larvae of bacteriosponges in general during their free-swimming period.

This study was partially funded by the project INTERGEN CTM2004-05265-C02-02/MAR from the CICYT (Spain). We thank Dr X. Turon, the Scientific-technical Services of the University of Barcelona and J.M. Fortuño (ICM-C.SIC) for sample processing and help with electron and scanning electron microscopy.

\section{REFERENGES}

Boury-Esnault, N., Ereskovsky, A., Bézac, C. \& Tokina, D., 2003. Larval development in the Homoscleromorpha (Porifera, Demospongiae). Invertebrate Biololgy, 122, 187-202.

Caralt, S. de, Agell, G. \& Uriz, M.J., 2003. Long-term culture of sponge explants: conditions enhancing survival and growth, and assessment of bioactivity. Biomolecular Engineering, 20, 339-347.

Enticknap, J.J., Nelly, M., Peraud, O. \& Hill, R.T., 2006. Characterization of a culturable alphaproteobacterial symbiont common to many marine sponges and evidence for vertical transmission via sponge larvae. Applied and Environmental Microbiology, 72, 3724-3732.

Ereskovsky, A.V. \& Boury-Esnault, N., 2002. Cleavage pattern in Oscarella species (Porifera, Demospongiae, Homoscleromorpha): transmission of maternal cells and symbiotic bacteria. Fournal of Natural History, 36, 1761-1775.

Ereskovsky, A.V. \& Tokina, D.B., 2004. Morphology and fine structure of the swimming larvae of Ircinia oros (Porifera, Demospongiae, Dictyoceratida). International Fournal of Invertebrate Reproduction and Development, 45, 137-150.

Jaeckle, W.B., 1995. Transport and metabolism of alanine and palmitic acid by field-collected larvae of Tedania ignis (Porifera, Demospongiae): estimated consequence of limited label translocation. Biological Bulletin. Marine Biological Laboratory, Woods Hole, 189, 159-167.

Jiménez, E. \& Ribes, M., 2007. Sponges as a source of dissolved inorganic nitrogen: nitrification mediated by temperate sponges. Limnology and Oceanography, 52, 948-958.

Johnston, I.S. \& Hildemann, W.H., 1982. Cellular organization in the marine demosponge Callyspongia diffusa. Marine Biology, 67, $1-7$.

Kaye, H.R. \& Reiswig, H.M., 1991. Sexual reproduction in four Caribbean commercial sponges. III. Larval behaviour, settlement and metamorphosis. Invertebrate Reproduction and Development, 19, $25-35$.
Leys, S.P. \& Reiswig, H.M., 1998. Transport pathways in the neotropical sponge Aplysina. Biological Bulletin. Marine Biological Laboratory, Woods Hole, 195, 30-42.

Lohr, J.E., Chen, F. \& Hill, R.T., 2005. Genomic analysis and characterization of a marine phage that infects a spongeassociated alpha-Proteobacterium. Applied and Environmental Microbiology, 71, 1598-1609.

Maldonado, M., Cortadillas, N., Trillas, M.I. \& Rützler, K., 2005. Endosymbiotic yeast maternally transmitted in a marine sponge. Biological Bulletin. Marine Biological Laboratory, Woods Hole, 209, 94-106.

Mariani, S., Piscitelli, M.P. \& Uriz, M.J., 2001. Temporal and spatial co-occurrence in spawning and larval release of Cliona viridis (Porifera: Hadromerida). Fournal of the Marine Biological Association of the United Kingdom, 81, 565-567.

Muricy, G., Bézac, C., Gallissian, M.F. \& Boury-Esnault, N., 1999. Anatomy, cytology and symbiotic bacteria of four Mediterranean species of Plakina Schulze, 1988 (Demospongiae, Homosclerophorida). Fournal of Natural History, 33, 159-176.

Piel, J., 2006. Bacterial symbionts: prospects for the sustainable production of invertebrate-derived pharmaceuticals. Current Medicinal Chemistry, 13, 39-50.

Rosell, D. \& Uriz, M.J., 1992. Do associated zooxanthellae and the nature of the substratum affect survival, attachment and growth of Cliona viridis (Porifera: Hadromerida)? An experimental approach. Marine Biology, 114, 503-507.

Sarà, M., 1971. Ultrastructural aspects of the symbiosis between two species of the genus Aphanocapsa (Cyanophyceae) and Ircinia variabilis (Demospongiae). Marine Biology, 11, 214-221.

Turon, X., Becerro, M.A. \& Uriz, M.J., 2000. Distribution of brominated compounds within the sponge Aplysina aerophoba: coupling of X-ray microanalysis with cryofixation techniques. Cell and Tissue Research, 301, 311-322.

Uriz, M.J., Turon, X. \& Becerro, M., 2001. Morphology and ultrastructure of the swimming larvae of Crambe crambe (Demospongiae, Poecilosclerida). Invertebrate Biology, 120, 295307.

Usher, K.M., Fromont, J., Sutton, D.C. \& Toze, S., 2004. The biogeography and phylogeny of unicellular cyanobacterial symbionts in sponges from Australia and the Mediterranean. Microbial Ecology, 48, 167-177.

Usher, K.M., Sutton, D.C., Toze, S., Kuo, J. \& Fromont, J., 2005. Inter-generational transmission of microbial symbionts in the marine sponge Chondrilla australiensis (Demospongiae). Marine and Freshwater Research, 56, 125-131.

Vacelet, J., 1975. Étude en Microscopie Électronique de l'Association entre Bactéries et Spongiaires du Genre Verongia (Dictyoceratida). Fournal de Microscopie et de Biologie Cellulaire, 23, 271-288.

Wilkinson, C.R. \& Vacelet, J. 1979. Transplantation of marine sponges to different conditions of light and current. Fournal of Experimental Marine Biology and Ecology, 37, 91-104.

Submitted 5 January 2007. Accepted 18 June 2007. 
